\title{
DOSSIÊ KANT
}

O III Colóquio Kant de Marília, realizado em setembro de 2008 a partir do tema "A 'Crítica da Faculdade de Julgar Teleológica'", contou com doze conferencistas, três deles provindos do exterior, dois dos quais, ao lado de outros três colegas, têm suas exposições ora publicadas pela Trans/Form/Ação.

Já inscritos no calendário científico-acadêmico nacional, os ColóquiosKant de Marília têm sido regularmente divulgados no exterior por meio da Kant-Forschungsstelle e da Società Italiana di Studi Kantiani, além de, no Brasil, pela Sociedade Kant Brasileira e pela Associação Nacional de PósGraduação em Filosofia. A publicação de parte de seu conteúdo sob a forma de artigos científicos na "Revista de Filosofia da Unesp" significa o ampliamento de sua contribuição aos debates em torno da filosofia crítica.

No presente caso, esse contributo será de certo modo ainda mais significativo, dado o evento ter abordado a segunda parte da Crítica da Faculdade do Juízo, a qual, embora considerada, não terá sempre merecido a devida atenção por parte da Kant-Forschung.

Ubirajara Rancan de Azevedo Marques 